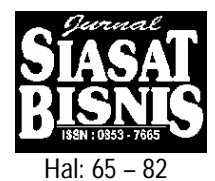

\title{
MANAJEMEN SDM DALAM KONTEKS GLOGAL: CROSS-CULTURAL MANAGEMENT
}

\author{
Andi Kusuma \\ Pasca Sarjana Master of Sains \\ Universitas Gadjah Mada
}

\begin{abstract}
Tulisan ini mencoba memberikan kerangka pikir bagi manajemen SDM terhadap perubahan lingkungan bisnis yang akan kita hadapi di masa yang akan datang. Walaupun harapan selalu mengarah kepada kesuksesan, tetapi angkatan kerja dan lingkungan kerja telah berubah secara radikal, sementara kebanyakan struktur kerja tidak berubah dengan cepat. Di dalam penulisan artikel ini, penulis mencoba mengajukan suatu visi mengenai hubungan kerja dengan fleksibilitas dan keinovativan, partnership, dan powersharing terhadap perubahan lingkungan bisnis serta tuntutan pekerjaan yang telah terjadi dewasa ini. Tujuannya adalah suatu lingkungan di mana semua anggota organisasi mempunyai sense of community dan sense of belonging.
\end{abstract}

ASUMSI-ASUMSI YANG MENDASARI CULTURE MANAGEMENT-Unsur-unsur esensial bagi kesuksesan organisasi?

Meskipun mendapatkan perhatian yang begitu tinggi selama tahun 1990-an, keinginan untuk mengelola/memanajemen corporate culture bukanlah hal yang baru. Hal tersebut sebenarnya telah mendapatkan perhatian dipertengahan 1980-an ketika muncul "pergerakan-pergerakan" yang menempatkan tuntutan bahwa kinerja organisasional yang superior (unggul) berhubungan dengan budaya-budaya yang mempunyai sifat koheren yang kuat, sesuai dengan tipe dan strategi organisasional. Hal ini kemudian terus diperdebatkan bahwa seharusnya terdapat tingkat kesesuaian yang tinggi antara struktur dan budaya organisasi, dan antara budaya dan strategi bisnis (Woodall, 1996).

Sebagai tambahan, globalisasi pasar dan kompetisi internasional memaksa perusahaan-perusahaan beroperasi di dalam suatu lingkungan multibudaya (multicultural environment). Demikian juga dengan adanya pola-pola migrasi dan media komunikasi transnasional seperti televisi satelit menciptakan populasi multibudaya (multicultural populations) di dalam pasar-pasar domestik dan membuka konsumen-konsumen menuju kebutuhan-kebutuhan dan perilaku-perilaku alternatif.

Beberapa usaha telah dibuat untuk mengembangkan pandanganpandangan integratif di dalam penelitian mengenai perilaku lintas budaya (cross-cultural behavior). Di beberapa kasus, para peneliti telah sukses memberikan model-model manajerial dengan jelas mengenai perilaku lintas 
budaya. Penulisan artikel ini mencoba memberikan gambaran sekali lagi tentang cross-cultural behavior serta mencoba menawarkan suatu framework untuk memahami perilaku lintas budaya. Menurut Luna dan Gupta (2001), perilaku lintas budaya dipengaruhi oleh beberapa faktor seperti diperlihatkan pada gambar 1.

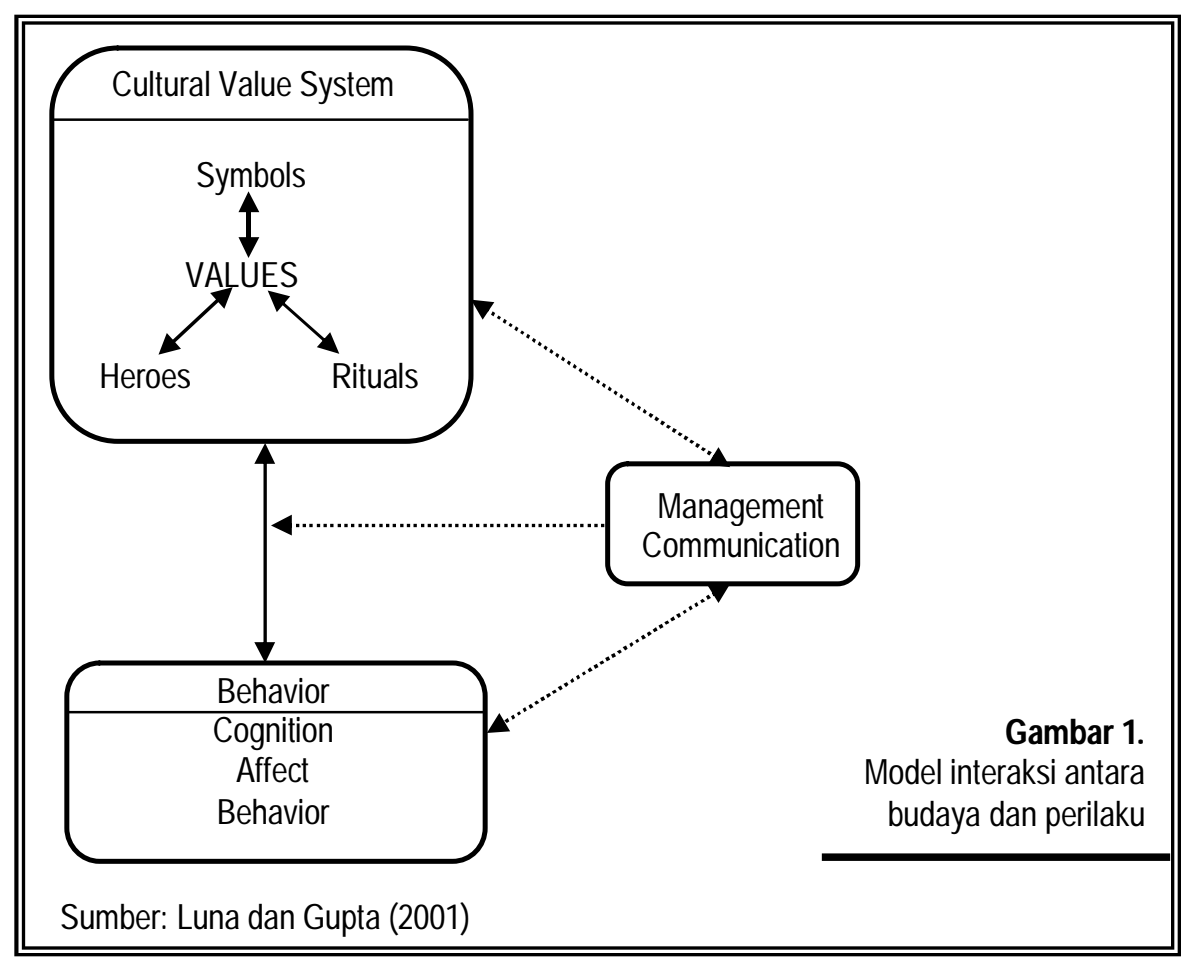

Gambar 1 melukiskan interaksi budaya dan perilaku, suatu model dari pengaruh saling timbal balik antara budaya dan perilaku. Perilaku seorang individu merupakan hasil dari sistem nilai (values) yang dimiliki individu tersebut untuk suasana/keadaan tertentu. Sistem-sistem nilai budaya individu dikembangkan sepanjang waktu sejalan mereka bersosialisasi dengan grup/kelompok tertentu. Budaya masyarakat/lembaga juga regional subculture dan nilai-nilai keluarga semuanya mempengaruhi pembentukan sistem nilai individu. Karenanya, sistem nilai budaya (cultural value system) memasukkan elemen-elemen budaya yang dimiliki individuindividu pada umumnya dengan grup-grup di mana mereka berada, hal ini bisa dipandang sebagai keunikan nilai-nilai idiosyncratic terhadap individu.

Seperti yang diperlihatkan di dalam model, budaya mempengaruhi perilaku, di mana budaya itu sendiri mendorong kembali manifestasi dari budaya. (Peter dan Olson, 1998). Perilaku yang dimiliki oleh seorang 
individu mungkin dipandang dan ditiru atau ditolak oleh individu yang lain. Hal tersebut kemudian menjadi norma-norma perilaku grup dan diidentifikasikan sebagai bagian dari budaya yang diperlihatkan di dalam populasi. Tindakan-tindakan manajemen (management's actions) bertindak sebagai suatu sarana untuk mentransfer arti-arti atau nilai-nilai yang secara kultural terdapat di lingkungan eksternal untuk diadopsi ke dalam organisasi, sehingga komunikasi yang digambarkan di dalam model merupakan suatu moderator utama dari pengaruh budaya terhadap perilaku. Kebanyakan riset-riset yang ada juga menyimpulkan pentingnya komunikasi untuk menyampaikan budaya yang ada di dalam suatu kelompok/grup.

Budaya mempengaruhi perilaku melalui manifestasi-manifestasinya, seperti yang diungkapkan oleh Hofstede, yaitu: values, heroes, rituals, dan symbols. Ini semua merupakan bentuk-bentuk di mana secara kultural penetapan knowledge disimpan dan diungkapkan. Karena itu, setiap budaya grup menghadapi manifestasi-manifestasi budaya yang berbeda pula.

Peran Pokok Values. Penelitian-penelitian terdahulu menyatakan bahwa values mempunyai peran pokok di antara manifestasi-manifestasi budaya yang lain dan bahwa hubungan antara manifestasi dan value dikarakteristikkan oleh hubungan yang saling mempengaruhi (mutual influence). Sebab itu, simbol-simbol (symbols) secara umum menyatakan nilai-nilai budaya. Melalui konsumsi ritual-ritual (rituals), konsumen barangbarang menjadi simbol dari nilai-nilai budaya. Pada saat yang sama, simbol mendorong kembali nilai-nilai, atau bahkan terkadang mengalihkan peran nilai (Luna dan Gupta, 2001).

Hubungan alami antara bahasa-sebagai-suatu-simbol (languageas-a-symbols) dan nilai-nilai telah menjadi subyek yang menarik untuk diperdebatkan. Beberapa peneliti menyatakan bahwa bahasa (language) mempengaruhi values, dan peneliti yang lain mengemukakan bahwa nilainilai budaya menentukan bentuk dari bahasa. Sangat memungkinkan bahwa hubungan ini bersifat berhubungan dua arah (bidirectional). Sebagai contoh, nilai-nilai budaya mungkin memotivasi pembentukan kata-kata yang mungkin tidak terdapat pada budaya lain. Pada saat yang sama, bahasa mungkin merupakan sumber dari nilai-nilai yang secara harfiah "tidak terpikirkan" ("unthinkable") di budaya lain karena terdapat kesenjangan istilah-istilah yang tepat untuk mendiskusikannya.

Definisi dari heroes secara tidak langsung menyatakan bahwa heroes adalah perwujudan dari nilai-nilai budaya. Heroes dipilih karena mereka adalah individu-individu atau grup/kelompok yang mewakili apa yang anggota dari grup/kelompok budaya mempercayainya. Hubungan antara nilai dan heroes dapat juga bersifat bidirectional. Seperti yang digambarkan oleh McCracken, arti-arti budaya baru dapat diciptakan 
dengan "cara sederhana. Penciptaan ini dilakukan oleh opini-opini leader yang membantu membentuk dan menyaring arti-arti budaya yang ada, mendorong pembentukan kembali kategori-kategori dan prinsip-prinsip" (Luna dan Gupta, 2001).

Definisi dari rituals mengimplikasikan bahwa ritual untuk sebagian besar merupakan bagian dari penegasan/penguatan values (affirmation of values). Akan tetapi, ritual dapat juga mempengaruhi nilai-nilai budaya dengan maksud di mana nilai-nilai mungkin direvisi kembali dan keberartian budaya dimanipulasi. Sebagai contoh, pertimbangkan upacara/tatacara dari penerimaan yang membuka atau memperkuat nilai-nilai tertentu yang ada pada individu yang belum kita kenal, sehingga membuat dirinya menjadi anggota grup.

Elemen-elemen perilaku. Elemen-elemen perilaku yang terdapat di gambar 1 diambil dari pekerjaan-pekerjaan terdahulu di dalam penelitian konsumen dan diperlihatkan/diungkapkan di dalam definisi American Marketing Association's mengenai perilaku konsumen sebagai "interaksi dinamis dari pengaruh dan kognisi, perilaku, dan lingkungan dimana manusia melakukan pertukaran aspek-aspek kehidupan mereka". Cognition berarti konstruk-konstruk atau proses-proses mengenai struktur memori atau gagasan-gagasan diri sendiri (self-construal). Affect berkenaan dengan proses pembentukan sikap/maksud dan outcomes-nya: sikap melalui suatu kesatuan, baik material (mis: produk) atau abstrak (mis: grup etnik). Perilaku termasuk pilihan-pilihan individu dan pola-pola perilaku, misalnya penggunaan media atau pembelanjaan makanan (Luna dan Gupta, 2001).

\section{ISU-ISU ETIKA YANG MUNCUL SELAMA PROSES PERUBAHAN BUDAYA}

Culture management merupakan area dari kebijakan dan praktekpraktek sumber daya manusia (SDM). Di dalam manajemen SDM hal ini menyediakan suatu kerangka referensi di mana sejumlah proses seperti rekrutmen, seleksi dan penilaian, manajemen kinerja dan pemberian reward serta pengembangan terjadi. Inisiatif-inisiatif culture management biasanya dilakukan ketika organisasi harus berhadapan dengan beberapa perubahan besar di dalam lingkungan bisnisnya, bahkan jika culture management dipandang sangat memungkinkan, masih terdapat pertanyaanpertanyaan yang mendasari asumsi-asumsi, tetapi perspektif yang masih terbatas pada budaya adalah di mana kebanyakan penyokong/pondasi perubahan budaya malahan membatasi dirinya sendiri serta membawanya ke dalam permasalahan etika (ethical problems). Frekuensi pertumbuhan masalah ini lebih dari 10 tahun terakhir telah membuat perimbangan- 
pertimbangan yang berhubungan dengan etika menjadi semacam wacana yang sangat mendesak (Woodall, 1996).

Terdapat beberapa pekerjaan di dalam pengembangan budaya yang akan menegakkan dan mempertimbangkan perilaku etika, dan beberapa pengujian terhadap bagaimana aspek-aspek keadilan organisasional (organizational justice) mungkin dikesampingkan oleh kampanye budaya yang "lebih fokus pada pembentukan nilai-nilai yang berhubungan dengan kinerja tanpa memberikan perhatian yang tepat terhadap konsekuensi etika dan legalitasnya". Mungkin kekosongan ini terjadi karena banyak dari culture management bersekolah di dalam corporate strategy atau change management, di mana terdapat sedikit perhatian diberikan kepada pertanyaan mengenai integritas etika dari perilaku manajerial dan konsekuensi-konsekuensinya kepada para pegawai. Bahkan, McClelland \& Burnham (1995) menyatakan bahwa banyak para manajer sebagai penyokong/penganjur culture management lebih menghargai nilai-nilai humanitarian, aktualisasi diri dan individualisme sehingga mereka "lebih banyak membantu" di dalam memecahkan masalah. Hal ini secara khusus mengkhawatirkan mengingat bahwa culture management tidak hanya menjadi bagian dari manajemen SDM saja, tetapi juga menyangkut semua level/fungsi di dalam suatu organisasi karena untuk menyusun arah dan "irama" dari para pegawai (anggota organisasi) haruslah terdapat koordinasi kebijakan dengan semua fungsi yang ada di dalam organisasi.

Dua area utama di mana isu ini muncul terutama terletak di dalam peran agen-agen perubah ( the role of change agents), dan outcomes etika dari proses the "unfreeze-change-refreeze".

Menurut Fisher Jr (2000), change agents seharusnya tidak merasa takut terhadap peringatan manajemen ketika mereka menjadi begitu antusias tentang pentingnya pembentukan tim kerja atau intervensiintervensi lain yang mungkin ingin dicapai. Mereka harus mengetahui keterbatasan mereka dan menterjemahkannya menjadi bahasa yang manajemen memahami dan berurusan dengan hal tersebut. Change agents harus membantu manajemen menciptakan iklim di mana orang dibiarkan untuk melakukan protes secara periodik tetapi dengan sopan daripada terjadi ketidakkonsistenan dan kasar, dan menginstruksikan kebijakan manajemen untuk melibatkan pihak ketiga, dan bagaimana hal itu dapat membantu manajemen menjadi mengerti, suportif, dan konsisten dengan pesan-pesannya dan pada akhirnya menciptakan suatu iklim di mana semua pegawai berpikir sebagai pemilik (think like owners).

Sedangkan di dalam proses "unfreeze-change-refreeze", organisasi seharusnya:

- Pertama, jika manajemen organisasi secara sadar mengharapkan untuk mengadopsi nilai-nilai yang dapat menyatakan tujuan-tujuannya, 
maka hal ini haruslah memungkinkan terjadinya dialog internal mengenai apa yang seharusnya diadopsi dan hubungannya yang lebih luas dengan nilai-nilai sosial. Misalnya, loyalitas individu kepada organisasinya juga dipengaruhi oleh hubungannya dengan loyalitasnya kepada keluarga dan grup kerjanya, dan di atas semua itu: komitmen organisasi kepada individu. Culture management yang tidak menyadari hal ini dan lebih senang melakukan komitmen satu sisi (menekankan produktivitas/profit, misalnya) akan kehilangan sesuatu yang sangat penting - rasa komunitas dan kepemilikan (sense of community and belonging). Karena itu, persyaratan yang diperlukan haruslah terjadi spin-offs untuk keluarga dan kehidupan pribadi, rekan sejawat dan beban-beban untuk masyarakat secara lebih luas (Woodall, 1996).

- Kedua, manajemen organisasi harus menciptakan kondisi di mana dialog dapat dengan mudah terjadi. Kejujuran di dalam penyampaian visi dan arah, keterbukaan dan fairness di dalam melakukan deal dengan pegawai, toleransi dan keamanan — semua ini dapat mendorong terjadinya dialog, bahkan ketika organisasi terdesak oleh pertimbangan-pertimbangan klasik semisal harga saham, public image, dan hubungannnya dengan kompetitor (Woodall, 1996).

Lingkungan bisnis yang mudah berubah, pasar uang dan adanya revisi-revisi strategi bisnis yang tidak tentu menciptakan situasi tertentu yang menyebabkan kedua persyaratan tersebut menjadi sukar dipahami untuk memanajemen perubahan budaya perusahaan; membuat penciptaan dialog internal dan tingkat tinggi dari integritas yang muncul hanyalah menjadi sebuah fantasi (Woodall, 1996). Karena itulah, tanpa ini semua perubahan budaya hanyalah suatu lingkaran kosong (hollow ring). Tetapi diharapkan, culture management tidak menjadi suatu contoh di dalam muslihat dan manipulasi

Berdasarkan uraian di atas, riset cross-cultural tradisional tidak lagi bisa digunakan untuk mengatasi permasalahan lintas batas (crossborder) yang dihadapi oleh perusahaan-perusahaan masa kini. Lebih jauh timbul suatu pertanyaan apakah riset-riset terdahulu sudah benar-benar memasukkan/mengukur pentingnya nilai terhadap perusahaan-perusahaan yang harus mendesain kebijakan-kebijakan untuk mengin-tegrasikan

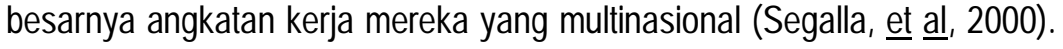
Begitu banyak teori tetapi tidak ada yang bisa dikatakan sebagai "grand" theory. Tidak adanya penegasan dan ketidaksesuaian pengetahuan, transformasional kepemimpinan, promosi bagi mereka yang mendukung nilai-nilai baru, penguatan dengan pemberian reward yang positif, manipulasi mitos-mitos dan simbol-simbol, dapat saja selalu membawa kepada perubahan nilai; tetapi seringkali tidak demikian. Masalahnya 
adalah bahwa tidak mudah memprediksi apa yang akan berhasil. Perubahan nilai bukanlah sesuatu yang eksak - bahkan ketika bekerja di bawah paksaan, kerelaan perilaku yang diperlihatkan akan selalu menjadi semacam topeng atau perasaan-perasaan ambivalensi.

Segalla, et al ( 2000) mengemukakan bahwa permasalahan utama riset cross-cultural terletak kepada bentuk quesioner yang digambarkan seperti sebuah kilatan potret dari ikan tropis, "kelihatannya" warnanya seperti kenyataan (padahal kalau ikan itu masuk lebih dalam lagi akan mempunyai warna lain). Akan tetapi menginterpretasikan apa arti dari polapola warna yang diperlihatkan memang tidak mudah karena kerangka referensi/berpikir kita juga sangatlah berbeda. Budaya kerja juga bersifat khusus atau tersendiri, ulet dan bersifat resisten terhadap perubahan Kemajuan-kemajuan di dalam metodologi riset mengindikasikan bahwa pendekatan-pendekatan baru untuk membangkitkan cultural knowledge mungkin akan menghasilkan hasil-hasil yang lebih baik.

Lebih jauh, sudah menjadi hal lumrah bahwa budaya bersifat statis dan/atau hanya berubah jika manajer memutuskan untuk berbuat sesuatu. Karenanya program-program perubahan budaya biasanya bersifat leadercentred, menekankan pada pentingnya sifat karismatik kepemimpinan dan tindakan-tindakan simbolis yang dipublikasikan dengan baik. "Launching" budaya baru dirasa membutuhkan tindak lanjut pemeliharaan, monitoring dan pembaharuan, di mana semuanya ini dikomandoi oleh manajemen. Akan tetapi, banyak riset yang menekankan pada kenyataan bahwa subkultur dapat bertahan dan dikembangkan, bahkan di dalam wajah formal, perubahan budaya yang diinspirasi secara manajerial. Di sisi lain, banyak juga yang mempercayai bahwa perbedaan dari subkultur-subkultur dan nilai-nilai merupakan resep yang mujarab untuk bisa sukses bagi organisasi, misalnya perusahaan-perusahan high-tech berbasis knowledge yang memperkerjakan profesional-profesional berkualitas tinggi (Woodall, 1996).

Karena itu, sudah menjadi semacam kebijaksanaan bahwa tingkatan tinggi dari komitmen dan kinerja menghendaki pegawai untuk mendukung nilai-nilai yang sejajar dengan visi manajerial. Ini merupakan semacam filosofi untuk suatu situasi kerja di mana orang diharapkan untuk menunjukkan kinerja sampai melebihi persyaratan tugas (job requirement) mereka, dan untuk mendorong perbaikan-perbaikan dalam kualitas atau kepuasan pelanggan. Oleh karenanya sekarang ini terlalu gegabah untuk mengasumsikan bahwa hanya manajer yang bisa mengkontrol budaya dan perubahan nilai-nilai (Woodall, 1996). 


\section{AKUISISI DAN MERGER}

Salah satu contoh yang paling mudah kita temui mengenai manajemen lintas (cross-cultural management) budaya adalah akuisisi dan merger. Salah satu isu kunci di dalam perubahan manajemen di negaranegara Asia dewasa ini adalah meningkatnya persekutuan (partnership) antara pebisnis di negara ini dengan rekan-rekan dari Eropa dan Amerika. Meningkatnya partnership telah menciptakan kesempatan yang begitu besar untuk kolaborasi secara global dan kemajuan. Begitu banyak crossnational dan cross-cultural business partners atau joint ventures yang sukses, dan banyak juga yang gagal. Partnership semacam itu, bagaimanapun juga, menciptakan keunikan permasalahan dan isu-isu yang berhubungan dengan keefektifan manajemen partnership: perbedaan tradisi, nilai-nilai, tindakan-tindakan dan tujuan-tujuan.

Ada beberapa pendekatan untuk membangun partnership dengan nasionalisme dan budaya yang berbeda. Graen \& Hui (1996) menggunakan penetapan third cultures sebagai fondasi di mana kesuksesan crossnational atau cross-cultural partnerships dapat dibangun.

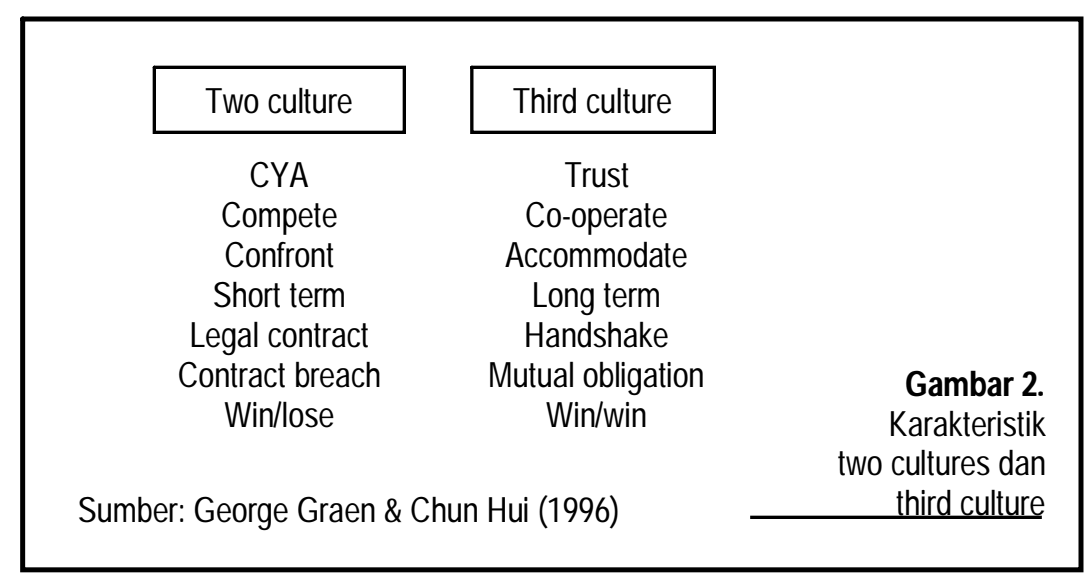

Seperti diperlihatkan gambar 2, dalam hubungan bisnis twoculture urusan-urusan bisnis dikarakteristikan oleh pihak yang tidak memihak/tidak berkepentingan dan sikap "cover-your-ass" (CYA). Hanya terdapat fokus jangka pendek, karenanya membawa kepada kompetisi dan konfrontasi bahkan dengan rekan bisnisnya sendiri. Partner bisnis mendasarkan pada perjanjian-perjanjian kontrak, dan menderita dari suatu kemungkinan terhadap pelanggaran kontrak. Partner bisnis, dalam kasus ini, dilibatkan di dalam suatu win-lose situation, di mana setiap partner berpikir untuk mendapatkan keuntungan, sedangkan partner lain akan memperoleh kerugian, atau paling tidak memperoleh keuntungan tapi tidak 
sebanyak yang diperoleh partner lainnya. Urusan-urusan bisnis crosscultural modern dipenuhi dengan hubungan partner semacam ini.

Third culture di lain pihak dikarakteristikan oleh individu-individu yang menjadi cultural "insider", membedakannya dengan "outsiders". Seorang cultural insider menghargai nilai-nilai budaya orang lain, dan menahan diri untuk menghakimi budaya lain. Third culture melibatkan saling menghargai dan menghormati. Karena sekarang ini semua merupakan partner bisnis sejati, mereka dapat berbagi di dalam urusan jangka panjang bisnis mereka, karenanya membawa ke arah kerjasama dan akomodasi. Partner bisnis ini dapat mempercayakan pada handshake dan kewajiban ketika mengerjakan bisnisnya. Mereka benar-benar dilibatkan di dalam win-win situation, di mana kedua partner dapat tumbuh dan membuat profit dengan kolaborasi satu sama lain.

Third culture esensial untuk mencapai kesuksesan cross-cultural business partnerships, karena budaya ini membiarkan lebih banyak fleksibilitas di dalam urusan bisnis dengan menyandarkan diri kepada kepercayaan (trust) sebagai pengganti dari proses pengadilan yang membosankan, mengurangi ketidakefisiensinan dengan mengendurkan mekanisme pengawasan eksternal, dan memaksimalkan usaha-usaha dan kemampuan pemanfaatan setiap partner.

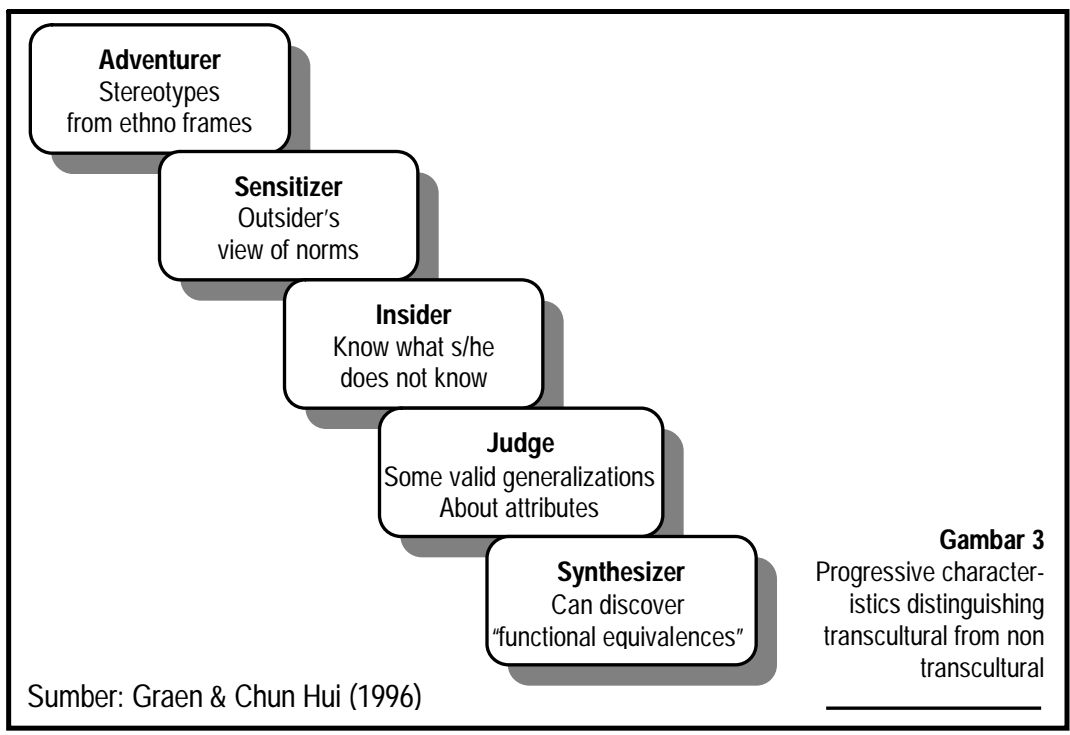

Bagaimana menciptakan third cultures? Untuk menanggapi isu-isu ini, Graen \& Hui (1996) memfokuskan kepada persyaratan personel, yaitu tipe orang yang diperlukan untuk menciptakan third cultures: Transculturals (gambar 3). Transculturals adalah mereka yang tumbuh melebihi sosialisasi 
budaya mereka sendiri sehingga mereka dapat mengerti perbedaan budaya dengan meminimalkan bias-bias dan membuat penilaian cross-cultural yang valid.

Licht (2001) menggunakan framework CVD (cultural value dimensions) dari psikologi cross-cultural dan mendemonstrasikan potensi kegunaannya untuk menganalisa masalah-masalah teori-teori crosscultural berdasarkan relevansinya dengan national culture untuk corporate governance systems dan securities regulations. Licht menyimpulkan bahwa national cultures, secara metafora, dapat dilihat sebagai the mother of path dependence dynamics dalam pengertian bahwa national culture memainkan suatu peran baik di dalam sumber dan di dalam pengembangan masa depan dari corporate governance systems.

\section{KONFLIK DAN IMPLIKASI MANAJERIAL}

Budaya organisasi itu dapat diciptakan untuk menyatukan anggotanya untuk pencapaian tujuan-tujuan organisasional secara efektif dan efisien yang dimengerti dan disepakati oleh anggota organisasi. Akan tetapi, perlu diingat bahwa organisasi itu sendiri juga merupakan suatu arena yang penuh dengan perselisihan dan konflik, dan beberapa yang paling panas adalah perselisihan terhadap nilai-nilai dasar apa yang harus diadopsi oleh organisasi di lingkungan itu. Fisher Jr., (2000) mengemukakan bahwa akar permasalahan tidak selalu terletak kepada orangorangnya, tetapi bisa berasal dari sistem, atau budaya. Seringkali disebutkan bahwa budaya merupakan sekumpulan norma, kepercayaan, nilai, keinginan, dan harapan yang ada di suatu tempat. Tidak ada satupun organisasi yang mempunyai budaya homogen, di dalamnya biasanya terdapat sub-sub kultur yang berbeda-beda di mana mereka sendiri juga merupakan sumber konflik. Usaha-usaha untuk menghapuskan/membasmi konflik adalah adanya self-defeating exercise, dan pada akhirnya menegaskan kepada keinginan manajerial untuk mengontrol.

Saling pengertian dan manajemen konflik karenanya memegang peran sentral di dalam praktek-praktek dan teori manajemen SDM. Perspektif tradisional menyatakan bahwa konflik seharusnya dihindari (Ivancevich dan Matteson, 1999), sementara perspektif yang lain mengharapkan manajer mendorong terjadinya konflik yang positif (Ertel, 1997) serta mencakup dan membantu perkembangan konflik sebagai salah satu alat pengembangan organisasi yang penting (Lee, 1998). Contoh lain seperti yang dikemukakan oleh Ang (2000) yang membandingkan kepercayaan terhadap uang, etika bisnis dan tanggung jawab sosial, dan guanxi (connections) di dalam melakukan analisis cross-cultural. 
Memang tidaklah tepat untuk membuat pernyataan generalisasi berdasarkan analisa terbatas tanpa menggunakan data representatif. Akan tetapi dari beberapa penelitian ataupun penulisan menggambarkan bahwa meskipun orang mungkin menggunakan bahasa yang umum, tetapi hal ini akhirnya hanyalah menjadi semacam topeng karena "understanding" yang diciptakan di sini kebanyakan hanyalah peniruan sikap/perilaku orang lain atau atasan. Orang masih belum bisa memahami apa makna sebenarnya dibalik sikap/perilaku itu. Menurut Lee (1998), "understanding" seharusnya digunakan secara luas dalam pengertian untuk memasukkan konsep, nilainilai dan emosi yang tiap-tiap dari kita mengungkapkannya lewat kata-kata (words) — kata adalah bentuk-bentuk simbol yang membawa keberartian atribut kita di dalam menjalani kehidupan.

Kebanyakan orang menyadari kapan mereka harus melibatkan diri dengan orang lain dan kapan tidak. Kita juga mengetahui bahwa orang juga sangat berbeda dari kita, tetapi kita masih belum melakukan stimulasi dan menghargai interaksi dengan mereka; yang lain, yang tidak benar-benar mirip dengan kita akan menaikkan kecurigaan kita, kita akan menganggapnya sebagai alien. Kita membuat teman dengan yang kita sukai, dan menghindari yang lain. Hal ini tidak bisa dilakukan ketika kita berada di lingkungan kerja. Ketika bekerja secara internasional, permasalahan perbedaan sangat menonjol. Di dalam situasi seperti ini, peran manajemen SDM sering kali harus menemukan arah untuk me-manage dan mengembangkan orang-orang yang secara alamiah membentuk persahabatan grup, kalau perlu sampai di luar lingkungan kerja.

Menurut pendapat penulis, semakin umum sesuatu diwarisakan kepada kita semakin besar commonality di dalam pengalaman kita, dan karenanya semakin sedikit perbedaan nyata di antara kita. Sisi lain adalah semakin nyata commonality, semakin saling berhubungan pesan-pesan, semakin mudah bagi kita untuk berasumsi bahwa penampilan itu "nyata" dan bahwa perbedaan di dalam pemahaman/pengertian itu menjadi minimal.

Kita mempunyai pandangan yang sangat berbeda mengenai peran orang-orang di dalam organisasi: permasalahan potensial dan karenanya perlu dikontrol secara secara kentara/tidak kentara; bagaimana orang dapat atau seharusnya di-manage (melalui konfrontasi, atau konsensus); dan akhirnya, bagaimana organisasi seharusnya beroperasi (jangka pendek dan task-focus, atau jangka panjang dan processual). Jika semua orang yang dilibatkan mengadopsi pendekatan konflik yang sama, maka usaha-usaha untuk memahami dan memanajemen perbedaan pandangan tersebut akan lebih mudah fokus pada isu yang ada.

Konflik memang potensial akan selalu muncul di dalam kehidupan organisasi. Manajemen konflik — yang kita pelajari dan kita kembangkan 
bersama - merupakan pokok sentral yang perlu kita pelihara sepanjang kehidupan organisasi.

\section{AMBIGUITY (KERANCUAN) DAN KOMUNIKASI}

Karena itulah pentingnya dilakukan komunikasi. Ditetapkan bahwa merger dan akuisisi diketahui mempunyai kegagalan seringkali diterangkan karena adanya perbenturan budaya perusahaan. Tidak adanya kejelasan interpretasi fenomena atau peristiwa yang menciptakan terjadinya ambiguitas di dalam organisasi. Secara ringkas, dari ke semua tipe perbedaan, ambiguitas terjadi karena tidak adanya atau ketidak cukupan informasi dan komunikasi. Kenyataannya, banyak para ahli yang menyebutnya sebagai lack of information. Dibandingkan dengan teori ambiguity yang ada, apa yang mungkin membuat ambiguity berbeda di dalam akuisisi adalah bahwa di dalam akuisisi, hampir semua anggota organisasi mengalami hal yang sama dalam hal ambigu. Ambigu berbeda, walau tipis, dari individu ke individu, tetapi biasanya terdapat pola-pola umum (collective) di antara semua individu. Tidak semua orang mengalami ambiguity negatif; beberapa mungkin melihat akuisisi sebagai suatu kesempatan (diterima sebagai sesuatu yang positif) (Risberg, 1997). Ambiguity dapat terjadi di dalam organisasi sejalan dengan penglaman budaya yang dialami oleh individu. Konsekuensinya, individu-individu yang berbeda di dalam organisasi dapat mengalami tipe-tipe yang berbeda dari ambiguity sepanjang waktu.

Akan tetapi, di dalam situasi tertentu, komunikasi malahan bisa menciptakan dan meningkatkan ambiguity. Jika komunikasi digunakan untuk menghomogenkan perbedaan budaya di dalam akuisisi tanpa menghargai adanya multikulturalisme di dalam organisasi, ketidakpastian dan ambiguity mungkin bisa muncul, karena kenyataannya, organisasi adalah multikultur atau ambiguity harus dikenali di dalam komunikasi di dalam kerangka perbedaan budaya untuk saling memahami satu sama lain. Komunikasi melewati batas-batas organisasi mungkin bisa memfasilitasi pemahaman setiap budaya yang dimiliki oleh orang/kelompok lain.

Karenanya masih diperdebatkan bahwa untuk memahami pertemuan budaya secara penuh, seseorang harus menerima, baik ambiguity dan komunikasi, pertimbangan serta akibat-akibatnya. Ambil contoh alternatif perspektif dalam hal merger dan akuisisi. Risberg (1997) mengembangkan konseptual framework yang menggunakan komunikasi selama proses akuisisi untuk memproduksi dan menegosiasikan beberapa arti dari ambiguity dan perbedaan budaya (Gambar 4). 


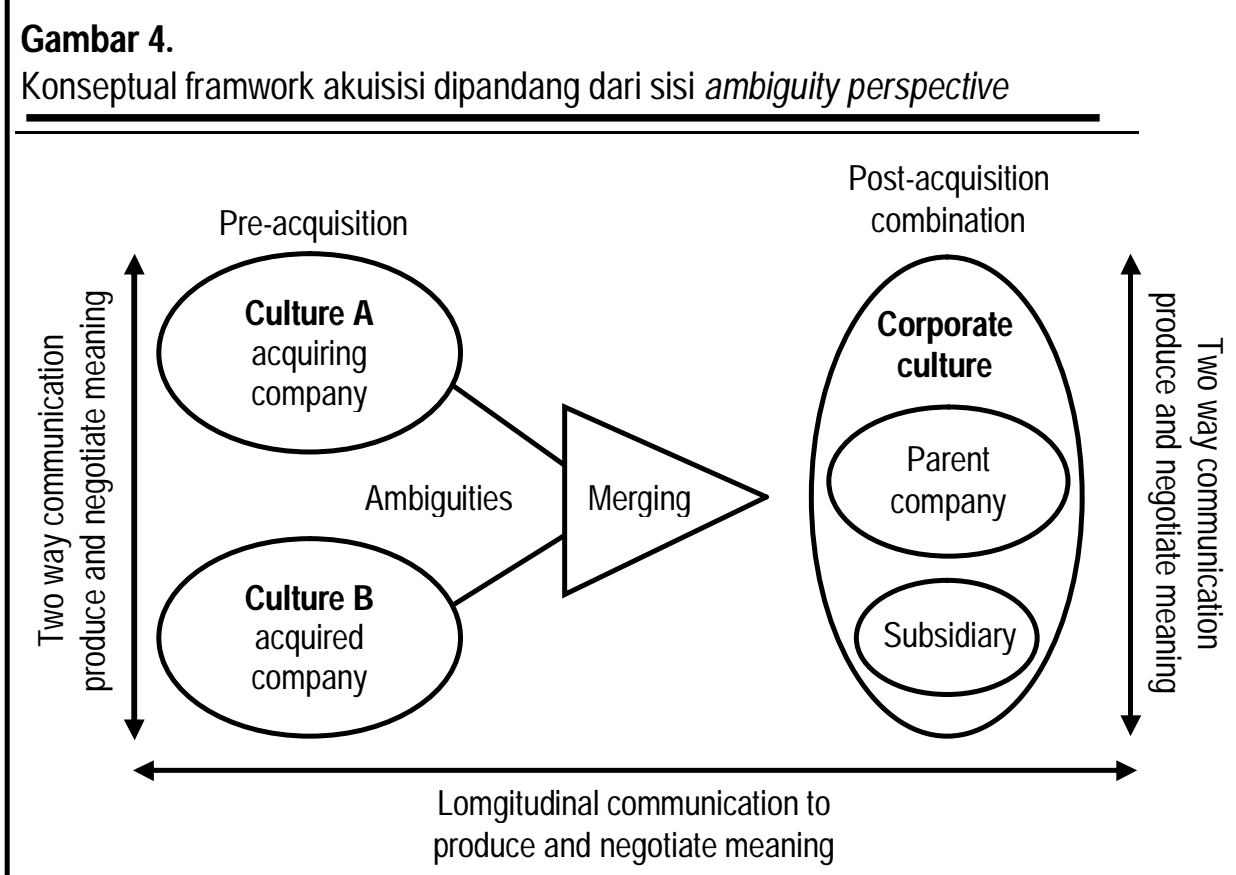

Sumber: Risberg, A. (1997)

Pertemuan itu mungkin membawa ambiguity dan ketidakpastian bagi pihak-pihak yang terlibat, karena selain miskomunikasi juga karena perbedaan background budaya yang dimiliki. Untuk membuat dua budaya bekerja sama, solusi seharusnya tidak untuk mencoba menghomogenkan mereka, tetapi mengakui ambiguity sebagai nilai-nilai dan asumsi-asumsi. Komunikasi seharusnya digunakan sebagai cara untuk memproduksi dan menegosiasikan arti-arti dari pertemuan budaya. Di dalam model ini, perbedaan antara dua perusahaan dihargai/dipandang dengan cara positif. Perusahaan yang diakuisisi tidak dipaksa untuk mengadopsi secara penuh kepada perusahaan induk. Tetapi, membiarkannya untuk memelihara perbedaan di dalam kerangka kerja budaya perusahaan secara keseluruhan. Pandangan ini akan memperbaiki kepada dua pihak bahwa perbedaan tidak harus membawa kepada cultural clashes. Perbedaan budaya tidak harus selalu dipandang sebagai sesuatu yang negatif di dalam akuisisi. Tetapi lebih jauh, di dalam perspektif ini, komunikasi secara kontinu digunakan untuk mengurangi ketidakpastian dan ambiguitas. Tanda panah mengindikasikan bahwa hal ini adalah komunikasi dua arah, antara perusahaan yang diakuisisi dan perusahaan yang mengakuisisi, dan bahwa komunikasi dilanjutkan kedalam keseluruhan proses akuisisi. 
Karenanya, komunikasi merupakan alat penting untuk me-manage perubahan, semacam akuisisi, tetapi hal tersebut haruslah konsisten untuk menghindari kebingungan.

\section{MENGEMBANGKAN BUDAYA SEBAGAI KEUNGGULAN KOMPETITIF}

Mendefinisikan konsep budaya perusahaan dan memperlihatkannya bagaimana hal ini mempengaruhi organisasi (baik positif maupun negatif) telah diuraikan secara singkat di atas. Perusahaan-perusahaan yang telah sukses menetapkan dan mendorong positive culture juga telah dijelaskan. Penulis menyimpulkan bahwa budaya yang efektif haruslah sesuai dengan nilai-nilai pegawai dan konsisten dengan lingkungan di mana organisasi tersebut beroperasi. Sementara ini merupakan jalan terbaik untuk menetapkan positive culture, dengan mana pegawai dapat mengidentifikasi selama masa pertumbuhan organisasi. Hal ini memungkinkan untuk merubah budaya yang ada di organsiasi. Perubahan semacam itu mungkin paling bagus apabila dikerjakan dengan modeling desired behavior di semua level manajemen dan dengan merencanakan peristiwa/kejadian yang menguatkan interaksi secara periodik di antara pegawai cross-functional (Sadri and Lees, 2000). Disimpulkan bahwa positive culture dapat menyediakan keuntungan kompetitif yang signifikan.

Fisher Jr. (2000) mengkategorisasikan budaya organisasi menjadi 3 macam: culture of comfort (manajer merupakan orangtua wali bagi pekerja yang berlaku sebagai anak). Culture of complacency (pekerja sebagai anak yang memanipulasi manajer sebagai orangtuanya sampai akhir hidupnya. Di sini pekerja dapat bertindak sesuai keinginannya). Sementara di dalam culture of contribution, manajer dan pegawai merupakan partner kolaboratif yang berlaku sebagai seorang manusia dewasa yang matang.

Menciptakan culture of contribution merupakan tantangan besar, karena kegagalan dan keinginan merupakan masalah besar yang selalu dihadapi oleh organisasi, dan budaya sering kali tidak dapat diuraikan karena keterbatasan pada bahasa. Bagaimana mendapatkan itu semua?

- Langkah pertama adalah mengenali bahwa tidak ada satu budaya perusahaan yang ideal. Iklim budaya di Indonesia tidaklah sama dengan budaya yang ada di angkatan kerja, tetapi merupakan kombinasi antara budaya mikro dan makro yang ada di dalamnya serta haruslah dimengerti secara keseluruhan.

- Kedua, suatu organisasi tidak mencari budaya, tetapi menciptakannya. Hal ini dengan masksud supaya dapat menangkap dengan jelas kepribadian, hasrat (desire), perjuangan, kegembiraan atau jiwa dari tempat itu (Fisher Jr., 2000) 
Permasalahan yang dihadapi oleh manajemen SDM sepertinya menekankan pada manajer yang diharapkan untuk mengambil tanggung jawab yang semakin meningkat untuk SDM; seperti beberapa literatur yang juga mengasumsikan bahwa hal ini akan terjadi. Misalnya Bhatt (2000); Bierly III, Kessler dan Christensen (2000) menekankan kepada cara-cara di mana learning adalah cara baru pembentukan tenaga kerja dan cara di mana jarak antara manajer dan bawahan semakin tererosi dan beberapa penulis (misalnya Byrne, 1993) telah mengeksplorasi perubahan peran/fungsi manajemen di dalam de-layered organisation dan organisasi yang semakin "ramping".

Lee (1998) menyarankan jenis-jenis kualitas yang mungkin diharapkan oleh "new" managers jika mereka ingin secara sukses mewujudkan "team player", diterima oleh rekan sejawat dan mampu bekerja secara fleskibel melintasi batas-batas tradisional organisasional di mana dia adalah seorang manipulator simbol-simbol organisasional yang dapat mengispirasi dan mempengaruhi orang lain dengan memanajemen iklim komunikatif melalui proses skill, sementara memelihara core ethical dan self-concept yang kuat. Penulis sangat menyukai visi manajemen karir di abad ke-21 dari Arthur dan Rousseau (1996) yang menyarankan perlunya perubahan yang paling fundamental terhadap asumsi-asumsi mengenai cara dunia bekerja, dan konsep protean careers-nya Hall (1996).

Itu semua mungkin berhasil di dalam struktur organisasi streamline yang harus berhadapan dengan situasi kompleks dan chaotic dari SDM, antara lain: motivasi-motivasi individu dan sejarah yang tidak mudah dimanage; kualitas-kualitas individu dan proses skill yang tidak mudah di"ajarkan".

Karena itu sistem feedback haruslah mendapat perhatian utama karena seseorang umumnya akan menindaklanjuti apa yang dia dapatkan setelah dia menerima feedback baik dari atasan atau rekan kerja dan orang-orang di sekitarnya.

\section{PENTINGNYA 3C (Commitment, Culture, Cost) UNTUK MERAIH SUKSES}

Penulisan artikel ini menggambarkan pokok- pokok pandangan bahwa terdapat tiga prasyarat fundamental yang perlu diperhatikan untuk menghasilkan manajemen berkualitas yaitu commitment, culture, dan cost (Laszlo, 1999).

\section{Commitment}

Secara khusus terdapat pengakuan oleh manajemen bahwa prinsip utama untuk melaksanakan perubahan adalah menyediakan "produk" dan "jasa" yang memenuhi ekspektasi pelanggan (internal dan 
eksternal). Keuntungan bagi organisasi adalah menghasilkan perbaikan, meningkatkan respon penerimaan, dan pada akhirnya meningkatkan profit. Ada tiga 3 komitmen yang perlu diperhatikan:

Komitmen dari top manajemen, diyakini sebagai faktor utama bagi keberhasilan implementasi program perubahan yang ada di dalam organisasi. Sudah merupakan tanggung jawab manajemen untuk menetapkan strategi melalui tujuan organisasi sekaligus memikirkan cara untuk meraihnya. Seberapa sulitnya lingkungan bisnis yang dihadapi, asalkan manajemen mengikutsertakan semua pihak untuk memikirkan jalan hidupnya organisasi, serta menunjukkan perilaku yang mendukung program perubahan bukan hal yang mustahil organisasi akan tetap mempunyai keunggulan kompetitif.

Komitmen dari sumber daya organisasi, kekompleksan dan skup yang begitu luas untuk diraih, maka keterbatasan sumber daya yang dimiliki organisasi perlu pengalokasian supaya memungkinkan semua pihak dan sektor menerimanya sehingga mereka bisa berpartisipasi. Prioritas utama adalah menyediakan pelatihan (training) bagi manajemen dan personel staf yang akan menjadi aktor utama bagi kesuksesan organisasi, dan waktu untuk memonitor serta menjamin kepastian inisiatif perbaikan.

Komitmen manajemen waktu. Kesuksesan implemantsi juga memerlukan pencocokan, pengujian, dan pertimbangan. Aturan/pengajaran program mengandung guidelines untuk operasional manajemen sehingga bisa diaplikasikan dengan permasalahan dan konteks yang tepat, menyediakan perbaikan peningkatan terhadap proses internal dan interaksi yang berorientasi kepada produk dan jasa. Pelatihan dan investasi waktu untuk mengimplementasikan program adalah pendekatan yang menyediakan payback bagi perbaikan efisiensi yang sejalan dengan kualitas produk dan jasa yang dihasilkan. Pemikiran yang baik sekali dan metode kualitas kerja yang tinggi merupakan kombinasi untuk tujuan jangka panjang. Keseluruhan perbaikan ini akan memungkinkan organisasi secara keseluruhan akan menjadi lebih dinamik dan responsif, yang pada akhirnya semakin kompetitif.

\section{Culture}

Untuk menjamin sukses, prinsip dasarnya adalah manajemen harus mempunyai sifat permeable di keseluruhan organisasi. Kerjasama, teamwork dan partnering merupakan contoh yang menguatkan sinergisme di antara semua fungsi. Pendekatan yang bersifat faktual dalam pembuatan keputusan, menghormati semua individu, mendorong inovasi, dan penekanan pada perbaikan bukannya fokus pada penyalahan untuk kesalahan yang dibuat, merupakan tanda-tanda dari learning organization. 


\section{Cost}

Kondisi-kondisi perekonomian yang sedang dihadapi juga perlu bagi perusahaan untuk mereview dan mengkontrol dengan ketat biayabiaya dan pengeluaran; pada saat krisis, manajemen sering kali menempatkan kualitas ke bagian belakang dan lebih menekankan pada keterbatasan finansial. Ironisnya, itu semua sebenarnya merupakan suatu kesempatan terbesar untuk meminimalkan kerugian operasional dengan cara bijaksana. Misalnya manajemen menanamkan sikap value-added approach kepada pegawai dan membiarkan mereka sendiri untuk memikirkan cara kerjanya selama ini serta untuk mengevaluasi keuntungan apa yang telah mereka berikan kepada para pelanggan.

\section{DAFTAR PUSTAKA}

Ang, S. H. (2000). The Power of Money: A Cross-Cultural Analysis of Business-Related Beliefs. Journal of World Business/35(1)/2000, pp. 43-60.

Arthur, M.B. dan Rousseau, D.M. (1996). A Career Lexicon for the 21 ${ }^{\text {st }}$ Century. Academy of Management Executive, Vol. 10, №. 4, pp.28-39

Bhatt, G.D. (2000). Information Dynamics, Learning and Knowledge Creation in Organization. The Learning Organization, Vol. 7, No. 2, pp. 89-98.

Bierly III, P.E., Kessler, E.H., \& Christensen, E.W. (2000). Organizational Learning, Knowledge, and Wisdom. Journal of Organizational Change Management, Vol. 13, No. 6, pp. 595-618.

Byrne, J.A. (1993). The Horizontal Corporation: It's about managing across, not up and down. Business Week, December 20, pp.44-49

Ertel, D. (1997). How to design a conflict management procedure that fits your dispute. Sloan Management Review,Summer, pp. 29-42.

Fisher, J. R. Jr. (2000). Envisioning a culture of contribution. Journal of Organizational Excellence, Winter 2000, pp. 47-54.

Graen, G. dan Hui, C. (1996). Managing changes in globalizing business: how to manage cross-cultural business partners. Journal of Organizational Change Management, Vol. 9, No. 3, 1996, pp. 62-72.

Hall, D.T. (1996). Protean careers of the $21^{\text {st }}$ century. Academy of Management Executive, vol. 10, No. 4, pp.8-16.

Ivancevich, J.M. dan Matteson, M.T. (1999). Organizational Beahvior and Management. McGraw-Hill, Boston. 
Laszlo, G.P. (1999). Implementing a quality management program \pm three Cs of success: commitment, culture, cost. The TQM Magazine, Vol. 11, No 4. pp. 231-237.

Lee, M. (1998). Understandings of conflict: a cross-cultural investigation. Personnel Review, Vol. 27, No. 3, pp. 227-242.

Licht, A.N. (2001). The mother of all path dependencies toward a crosscultural theory of corporate governance system. Delaware Journal of Corporate law, Vol. 26, pp. 147-205.

Luna, D. dan Gupta, S.F. (2001). An integrative framework for cross-cultural consumer behavior. International Marketing Review, Vol. 18, No. 1, pp. $45-69$.

McClelland, D.C. dan Burnham, D.H. (1995). Power is the great motivator. Harvard Business Review, January-February, pp. 126-139.

Peter, J.P. dan Olson, J.C (1998). Consumer Behavior and Marketing Strategy. McGraw-Hill, Boston, MA.

Risberg, A. (1997). Ambiguity and communication in cross-cultural acquisitions: towards a conceptual framework. Leadership \& Organization Development Journal, 18/5, pp. 257-266.

Sadri, G. dan Lees, B. (2000). Developing corporate culture as a competitive advantage. Journal of Management Development, Vol. 20, №. 10, pp. 853-859.

Segalla, M., Fischer, L., dan Sandne, K. (2000). Making Cross-cultural Research Relevant to European Corporate Integration: Old Problem New Approach. European Management Journal Vol. 18, No. 1, pp. 38-51.

Woodall, J. (1996). Managing culture change: can it ever be ethical?. Personnel Review, Vol. 25, No. 6, pp. 26-40. 